\title{
ISOTOPIC EVIDENCE FOR PALEOCLIMATIC AND PALEOATMOSPHERIC VARIATIONS FROM THE PALEOGENE BIGHORN BASIN SEQUENCE
}

$\mathrm{KOCH}^{\star}$, Paul L., Carnegie Inst. of Washington, Geophysical. Lab., 5251 Broad Branch Rd., NW, Washington, DC 20015 U.S.A.; DETTMAN, David L. and ZACHOS, James C., Dept. of Geol. Sci., Univ. of Michigan, Ann Arbor, MI 48109 U.S.A.

Land mammal faunas changed dramatically from the late Paleocene to the Eocene. This interval was marked by substantial paleoceanographic changes, including marine warming, and mass extinction of benthic foraminifera. Yet study of the impact of marine events on continental climates and faunas is problematic, due to imprecision in marine/continental correlation.

Oxygen isotope measurements of paleosol carbonates, mammals, and bivalves from the Paleogene Bighorn Basin can be used to estimate mean annual temperature (MAT). The $\delta 180$ of paleosol carbonate is controlled by two factors: the $\delta 180$ of the groundwater from which it crystallizes, and the temperature during crystallization. Because mammals and bivalves secrete mineral in a biologically-restricted range of temperatures, their isotopic compositions serve as proxy indicators of surface water $\delta 180$. The difference in $\delta 180$ between these proxy indicators of water and paleosol carbonate is used to calculate MAT through application of standard oxygen isotope thermometry relationships. Calculated temperatures vary significantly throughout the interval, with high values $\left(>20^{\circ} \mathrm{C}\right)$ in the late Paleocene, lower values in the earliest Eocene $\left(10-20^{\circ} \mathrm{C}\right)$, and renewed warmth later in the Early Eocene.

In modern temperate regions, MAT and the $\delta 180$ of precipitation are closely correlated. Estimates for Paleocene/Eocene surface waters from tooth apatite and bivalves range from -8 to $-12 \%$ (SMOW). Today, precipitation with values this low is usually found in cold regions $\left(0-10^{\circ} \mathrm{C}\right)$. These temperature estimates are too low in light of other isotopic and paleobotanical indicators, which suggest very warm temperatures in the Bighorn Basin during the Paleogene. We hypothesize that vapor transport to the region was substantially different than at present. A potential model may be Amazonia, where wet season air masses lose up to $80 \%$ of their water vapor as they move across the basin, resulting in 180-depleted rainfall despite a warm climate.

Variations in $\delta 13 \mathrm{C}$ provide a tool for marine/continental correlation. Carbon in tooth apatite and soil carbonate is derived from plants, which fix atmospheric $\mathrm{CO}_{2}$. Atmospheric $\mathrm{CO}_{2}$ is, in turn, in isotopic equilibrium with marine carbonate. Because of these links, marine carbonate, land plants, land mammals, and soil carbonate should exhibit coupled carbon isotope variations. In the Paleogene, when $\mathrm{C}_{3}$ plants dominated floras, isotopic variations due to shifting floral composition, such as those documented in the Miocene Siwalik Sequence, could not occur. Paleogene continental and marine carbon isotope records are tightly coupled. In particular, there is an unusual marine carbon isotope excursion immediately preceding the Paleocene/Eocene boundary, which corresponds precisely to the major paleoceanographic changes and the extinction of benthic foraminifera. Tooth apatite and soil carbonate from the Paleogene Bighorn Basin also record this excursion, which occurs at the base of the Wasatchian, where perrisodactyls, artiodactyls, and modern primates first appear. Carbon isotopes allow tight marine/continental correlation of the Paleocene/Eocene boundary, and demonstrate that major biologic and climatic events at this time were globally synchronous. 